\title{
Changes In Various Hormone Levels In The Rabbit Traumatic Facial Nerve Injury Model
}

\author{
'Zeliha KAPUSUZ, ${ }^{2}$ Mahmut ÖZKIRIṢ, ${ }^{3}$ Muzaffer GENCER, ${ }^{4}$ Ayșe Yeșim GÖÇMEN, ${ }^{5}$ Yusuf Kenan DAĞLIOĞLU \\ ${ }^{1}$ Department of Otolaryngology, Head and Neck Surgery, İstinye University Medical Faculty, Associate Professor \\ ${ }^{2}$ Department of Otolaryngology, Head and Neck Surgery, Acıbadem Hospital, Kayseri, Associate Professor \\ ${ }^{3}$ Department of Anesthesia and Resuscitation Istinye University Liv Hospital, Assistant Professor \\ ${ }^{4}$ Department of Biochemistry, Bozok University Medical Faculty, Associate Professor \\ ${ }^{5}$ Medical Sciences Research and Application Center, Cukurova University, Associate Professor
}

\begin{abstract}
Objectives: We aimed to look into potential associations between specific biomarkers and trauma to Cranial Nerve VII (CNVII) in a rabbit model, focusing on whether endocrine studies have potential as biomarkers in this context.
\end{abstract}

Methods: 30 adult New Zealand rabbits with intact facial muscles were used for the research. Each animal underwent identical surgery by the same surgeon. The facial nerve divisions were exposed by incising below the level of the mandible. After dissection of the skin and subcutaneous layers, the buccal division of CNVII was located with the nerve stimulator and microscopic dissection and a section of nerve $10 \mathrm{~mm}$ long was excised in each case from the buccal branch of CNVII. Blood samples were drawn 8 weeks and 12 weeks after nerve injury had been surgically induced. The samples from day 1 , week 4 and week 8 were tested for the following levels: Testosterone, oestrogen, progesterone, free T3 and T4, Cancer antigen 19-9 (Ca19-9), folate, TPSA, FPSA, FSH, LH, CA15.3, CAE, AFP and prolactin.
Results: The levels of free T3 and T4 as well as testosterone, were down at 4 th week, but at 8 weeks each had increased. Ca19-9 levels were also above the baseline. At 4 weeks, whilst oestrogen had markedly risen, progesterone had fallen. The statistical significance of the change in levels of free T3 and T4, testosterone, oestrogen, progesterone and FPSA was evaluated. For the group of animals with induced paralysis, the association between the lesion and testosterone, oestrogen, progesterone, free T3 and T4, Ca19-9, and folate levels were strong and at the level of statistical significance.

Conclusion: There were statistically significant alterations in the serum levels of free $\mathrm{T} 3$ and $\mathrm{T} 4$, testosterone, oestrogen, progesterone and FPSA at the 4 and 8 week intervals post surgically-induced CNVII injury. It is likely that rabbit pathophysiology resembles human pathophysiology in nervous injury, hence these six biomarkers may be of value in managing trauma or idiopathic degeneration of CNVII in humans. The authors hope this study will pave the way for future research in this area.

Keywords: Injury, facial nerve, hormones

\section{Introduction}

The facial musculature is principally innervated by cranial nerve VII (CNVII), thus damage to this supply causes complete muscular paralysis of the face on the same side as the injury. ${ }^{[1]}$ Trauma to the skull and facial skeleton often result in damage to the peripheral branches of CNVII and the resulting loss of function may be both severe and ongoing. ${ }^{[2]}$ Whilst there are now better outcomes in injuries involving complete transection of the nerve thanks to microsurgery, for a subgroup of cases with CNVII injury, the residual functional deficits are still a cause for concern.
Correspondence: Zeliha KAPUSUZ

İstinte unv. Liv Hospital Esenkent/Istanbul

E-mail: drzeliha19@hotmail.com

Received: July 10, 2018; Accepted: July 25, 2018
Online available at:

www.entupdates.org DOI: $10.32448 /$ entupdates.45899 
[3] Potential problems that may remain include undue exposure of the cornea, which may develop ulcers and lead to visual impairment, hypersalivation, dysarthric speech and leakage from the oral cavity. These deficits are not infrequently accompanied by a loss of self-confidence and a tendency to withdraw socially. ${ }^{[2]}$

There is a need for deeper knowledge concerning the relationship between neurological trauma and biochemical markers (biomarkers) to assist with the discovery of novel agents and methods to promote neuronal regrowth.

Biomarkers are molecules of endogenous origin, the levels of which are taken to reflect disease onset, progression and treatment response. They are of growing significance in nervous system trauma to augment other investigatory diagnostic techniques such as electroencephalography, evoked sensorimotor responses, transcranial vascular ultrasonography, near-infrared spectroscopic techniques or other imaging modalities. Several proteins that originate from the nervous system are now known and they are being evaluated at present for their ability to elucidate how severe injury is, what the likely prognosis will be, and to see if they can cast light on the level of cell injury and the molecular pathways involved when neurones are damaged..$^{[4]}$ At the time of writing, a biomarker that can be used routinely in the context of diagnosing and managing CNVII damage is lacking. This research therefore aimed to look into potential associations between specific biomarkers and trauma to CNVII in a rabbit model, focusing on whether endocrine studies have potential as biomarkers in this context.

\section{Materials and Methods}

\section{Animals}

30 adult rabbits, male and female, of New Zealand White type and with a weight between 2.5 and $3.2 \mathrm{~kg}$ each were utilized for the research. Only those animals whose facial muscles were intact were used. Ethical approval for this study was obtained from the Ethics Committee of the Çukurova University Faculty of Medicine. Careful precautions were taken to keep suffering by the animals at the lowest level and the minimum number of animals consistent with obtaining a statistically significant result were used. The animals were held under fixed environmental conditions - ambient temperature of $25^{\circ} \mathrm{C}$ with relative humidity of between $10 \%$ and $55 \%$. There was an unlimited access to standard feed material and water.

Each animal underwent identical surgery by the same in- dividual. Anesthesia consisted of $10 \mathrm{mg} / \mathrm{kg}$ xylasine hydrochloride (Rompun ${ }^{\circledR}$, Bayer Pharmaceuticals, Turkey) and $50 \mathrm{mg} / \mathrm{kg}$ ketamine hydrochloride (Ketalar ${ }^{\circledR}$, Eczacibasi Pharmaceuticals, Turkey). Prior to administering anesthesia, atropine was given subcutaneously to provide antispasmodic and anticholinergic cover. The area to be operated upon was first sterilized using iodine-povidine (Batticon ${ }^{\circledR}$ solution, Adeka Pharmaceuticals, Turkey).

\section{Facial Nerve Surgery}

Surgery was undertaken using sterile technique and the operating microscope. The rabbit was lain on its side and the area anterior to the auricle and the left side of the neck were shaved. The facial nerve divisions (dorsal buccal, ventral buccal and marginal mandibular) were exposed by incising below the level of the mandible. After dissection of the skin and subcutaneous layers, the buccal division of CNVII was located with the facial nerve stimulator and microscopic dissection and a section of nerve $10 \mathrm{~mm}$ long was excised in each case from the buccal branch of CNVII $(n=25)$ (Figures 1-3). Postoperatively the rabbits were kept on heated pads and then placed in separate cages where they could eat and drink water ad libitum. Recovery from surgery was in all cases uncomplicated.

\section{Blood samples and biochemical measurements}

Blood samples were drawn 8 weeks and 12 weeks after nerve injury had been surgically induced. First, the animals were fasted for 12 hours. The samples were centrifuged at $4^{\circ} \mathrm{C}$, then divided into no more than three aliquots to be deep frozen at $-80^{\circ} \mathrm{C}$ prior to analysis. The samples from day 1 , week 4 and week 8 were tested for the following levels: Testosterone, oestrogen, progesterone, free $\mathrm{T} 3$ and T4, Ca19-9, folate, TPSA, FPSA, FSH, LH, CA15.3, CAE, AFP and prolactin. The assays were performed by means of the Abbott Architect 1000i analyzer, using the manufacturer's own kits for CMIA (Chemiluminescent Microparticle Immunoassay).

\section{Statistical analysis}

The means plus standard errors were noted for each assay and the Statistical Package for Social Sciences version 17.0 was used for analysis. One-way ANOVA was used to analyze differences between groups. Comparisons were performed by Tukey procedure post hoc and correlation was analyzed using the Pearson test. A value of $\mathrm{p}<0.05$ was taken to indicate statistical significance. 


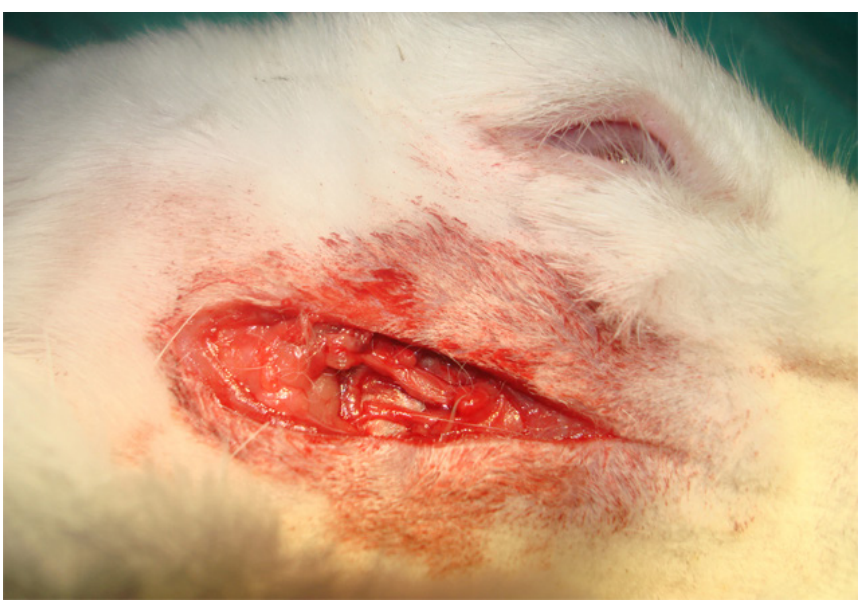

Figure 1. Exposure of the buccal branch of CNVII

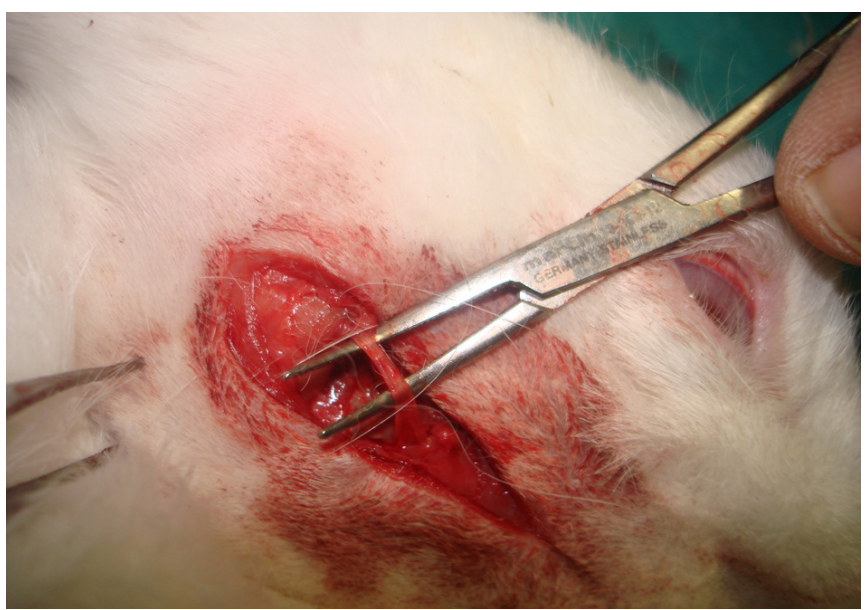

Figure 2. Dissection of the buccal branch of CNVII

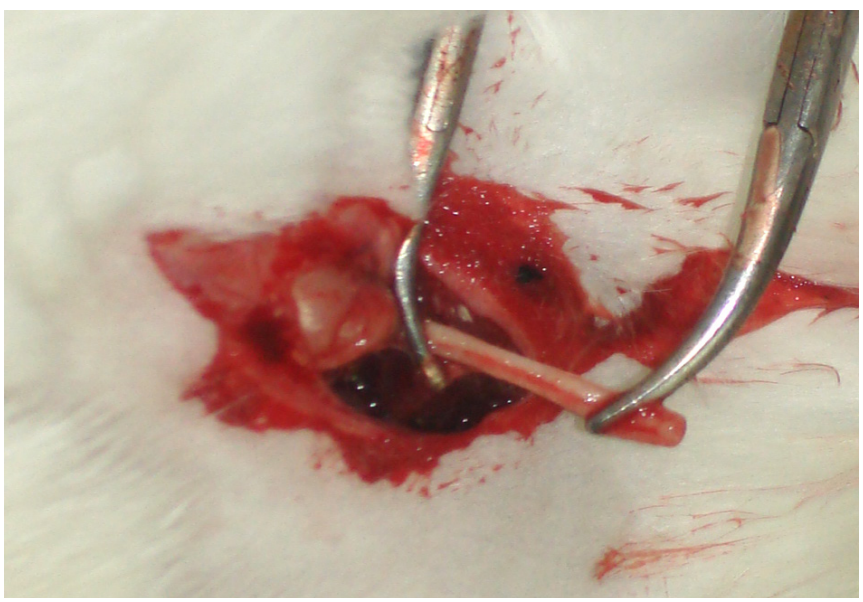

Figure 3. Excision of the buccal branch of CNVII

\section{Results}

The 3 groups can be compared in Table 1, showing the situation prior to surgery, at 4 and 8 weeks post-surgically and at the point the experiment was terminated. At 4 weeks, the levels of free $\mathrm{T} 3$ and $\mathrm{T} 4$ as well as testosterone were down, but at 8 weeks each had increased. Ca19-9 levels were also above baseline. At 4 weeks, whilst oestrogen had markedly risen, progesterone had fallen. The statistical significance of the change in levels of free $\mathrm{T} 3$ and $\mathrm{T} 4$, testosterone, oestrogen, progesterone and FPSA was evaluated. For the group of animals with induced paralysis, the association between the lesion and testosterone, oestrogen, progesterone, free T3 and T4, Ca19-9, and folate levels were strong and at the level of statistical significance.

\section{Discussion}

Trauma to the skull and facial skeleton frequently causes damage to the peripheral branches of CNVII and the resulting loss of function may be both severe and ongoing. Complete transection of CNVII can be better treated currently as a result of improved methods in microsurgery for remediating nerve injury. The treatment for partial nerve transection, by contrast, is medical, and thus only progress in drug discovery or novel methods aimed at regenerating neurones can improve the prognosis for such patients. ${ }^{[2]}$

For this study, rabbits were considered preferable to mice for disease model as their axonal recovery processes from crush injury are more similar to those of humans (chromatolysis preceding restoration of neuronal function) than those seen in mice..$^{[5]}$ Anatomically, CNVII in rabbits resembles that of humans.

"Stress response" refers to a pattern of endocrine and metabolic alterations subsequent upon trauma or insult that forms an element of the larger systemic response, involving, as it does, biochemical, endocrine, immune and hematological adaptations. ${ }^{[6]}$ Ischemia and trauma to neural tissues (such as CNVII) result in lesions both directly (primary insult) and indirectly (secondary to endogenous mediator activity). Trauma to CNVII may result in a cascade of biochemical and pathological adaptations leading to cellular necrosis and loss of function. The first adaptations include the hydrolytic conversion of membrane components into fatty acids, the synthesis of bioactive eicosanoids and production of reactive oxygen species (ROS) through oxidative degradation. ROS are the principal means through which cellular injury occurs. Peroxidation 
Table 1. Comparison of various biochemical markers.

\begin{tabular}{|c|c|c|c|c|}
\hline Parameters & $\begin{array}{c}\text { GROUP A } \\
(n=17)\end{array}$ & $\begin{array}{c}\text { GROUP B } \\
(n=17)\end{array}$ & $\begin{array}{c}\text { GROUP C } \\
(n=17)\end{array}$ & p \\
\hline $\begin{array}{l}\text { FREE T3 } \\
(\mathrm{pg} / \mathrm{ml})\end{array}$ & $2.62 \pm 0.95$ & $2.76 \pm 0.69$ & $2.90 \pm 0.54$ & $<0.005$ \\
\hline $\begin{array}{l}\text { FREE T4 } \\
\text { (ng/ml) }\end{array}$ & $0.55 \pm 0.21$ & $0.44 \pm 0.09$ & $0.60 \pm 0.17$ & $<0.05$ \\
\hline $\begin{array}{l}\text { FSH } \\
(\mathrm{mU} / \mathrm{ml})\end{array}$ & $0.03 \pm 0.00$ & $0.28 \pm 0.00$ & $0.03 \pm 0.00$ & $<0.005$ \\
\hline $\begin{array}{l}\text { TESTOSTERON } \\
(\mathrm{ng} / \mathrm{ml})\end{array}$ & $0.50 \pm 0.33$ & $0.16 \pm 0.18$ & $0.12 \pm 0.04$ & $<0.005$ \\
\hline $\begin{array}{l}\text { ESTRADIOL } \\
(\mathrm{pg} / \mathrm{ml})\end{array}$ & $69.1 \pm 13.86$ & $37.59 \pm 12.104$ & $47.00 \pm 10.93$ & $<0.005$ \\
\hline $\begin{array}{l}\text { PROGESTERON } \\
(\mathrm{ng} / \mathrm{ml})\end{array}$ & $2.98 \pm 2.55$ & $4.83 \pm 3.56$ & $1.08 \pm 0.44$ & $<0.005$ \\
\hline $\begin{array}{l}\text { FREE PSA } \\
(\mathrm{ng} / \mathrm{ml})\end{array}$ & $0.00 \pm 0.00$ & $0.00 \pm 0.00$ & $0.00 \pm 0.00$ & $<0.005$ \\
\hline $\begin{array}{l}\text { TOTAL PSA } \\
\text { (ng/ml) }\end{array}$ & $0.00 \pm 0.00$ & $0.00 \pm 0.00$ & $0.00 \pm 0.00$ & 1 \\
\hline $\begin{array}{l}\text { FOLAT } \\
(\mathrm{ng} / \mathrm{ml})\end{array}$ & $0.00 \pm 0.00$ & $0.00 \pm 0.00$ & $0.00 \pm 0.00$ & 1 \\
\hline $\begin{array}{l}\mathrm{LH} \\
(\mathrm{mU} / \mathrm{ml})\end{array}$ & $9.27 \pm 4.16$ & $9.35 \pm 4.70$ & $17.15 \pm 2.64$ & 0 \\
\hline $\begin{array}{l}\text { CEA } \\
(\mathrm{ng} / \mathrm{ml})\end{array}$ & $0.00 \pm 0.00$ & $0.00 \pm 0.00$ & $0.00 \pm 0.00$ & 1 \\
\hline $\begin{array}{l}\text { CA 19-9 } \\
(\mathrm{U} / \mathrm{ml})\end{array}$ & $052 \pm 0.09$ & $0.50 \pm 0.00$ & $0.05 \pm 0.00$ & 0.37 \\
\hline $\begin{array}{l}\text { CA-125 } \\
(\mathrm{U} / \mathrm{ml})\end{array}$ & $2.10 \pm 1.30$ & $1.00 \pm 0.10$ & $2.10 \pm 0.56$ & 0,00 \\
\hline $\begin{array}{l}\text { CA 15-3 } \\
(\mathrm{U} / \mathrm{ml})\end{array}$ & $0.50 \pm 0.00$ & $0.50 \pm 0.00$ & $0.50 \pm 0.00$ & \\
\hline PROLACTIN (ng/ml) & $0.50 \pm 0.00$ & $0.50 \pm 0.00$ & $0.50 \pm 0.00$ & \\
\hline
\end{tabular}

of lipid typically occurs by involvement of superoxide, hydroxyl or ferryl moieties.

Laboratory investigations may help to define how injury occurs as well as delimit a period in which it is beneficial to attempt therapeutic remediation - an issue of clinical as well as economic significance. The availability of suitable investigations (i.e. biomarkers) may greatly assist with defining probable outcomes to aim for in planning medical care. ${ }^{[7]}$ Biomarkers should be isolable from plasma and their level should reflect the severity of the neural insult. Biomarkers in blood or cerebrospinal fluid might point to what types of cells or what cellular function is being im- paired. Early results in their use for diagnosis of neoplasia, cardiac failure, infectious disorders and genetic conditions have been encouraging.

Currently the biomarkers with most widespread acceptance are $\mathrm{CK}-\mathrm{MB}$ (the $\mathrm{MB}$ isoform of creatine kinase) and the troponins, which find application as the primary way to confirm a suspected acute myocardial infarction, replacing ECG in this regard. ${ }^{[8]}$ Neuron-specific enolase ${ }^{[9-11]}$, S100B ${ }^{[12,13]}$, myelin-basic protein ${ }^{[14]}$, glial fibrillary acidic protein ${ }^{[10,12]}$ and cleaved tau protein ${ }^{[15]}$ have all been put forward as potentially of value in predicting prognosis following traumatic brain injury from a moderate to high 
degree of severity. Of these potential biomarkers, S100B has received the most interest. Studies investigating the outcome in low severity neural injury secondary to trauma have used S100B as a possible marker.

This research investigated biomarkers experimentally. There were statistically significant alterations in the serum levels of free T3 and T4, testosterone, oestrogen, proges-

\section{References}

1. Odebode TO, Ologe FE. Facial nerve palsy after head injury: Case incidence, causes, clinical profile and outcome. J Trauma 2006;61:388-91.

2. Diaz LM, Steele MH, Guerra AB, et al. The role of topically administered FK506 (tacrolimus) at the time of facial nerve repair using entubulation neurorrhaphy in a rabbit model. Ann Plast Surg 2004;52:407-13.

3. Wu G, Ju L, Jin $\mathrm{T}$, et al. Local delivery of recombinant human bone morphogenetic protein-2 increases axonal regeneration and the expression of tau protein after facial nerve injury. J Int Med Res 2010;38:1682-8.

4. Cata JP, Abdelmalak B, Farag E. Neurological biomarkers in the perioperative period. Br J Anaesth 2011;107:844-58.

5. Costa HJ, Silva CF, Korn GP, Lazarini PR. Posttraumatic facial nerve regeneration in rabbits. Braz J Otorhinolaryngol 2006; 72:78693.

6. Mukhtar AM, Obayah EM, Hassona AM. The use of dexmedetomidine in paediatric cardiac surgery. Anesth Analg 2006;103:52-6.

7. Kövesdi E, Lückl J, Bukovics P, et al. Update on protein biomarkers in traumatic brain injury with emphasis on clinical use in adults and pediatrics. Acta Neurochir (Wien) 2010;152:1-17.

8. Lewandrowski K, Chen A, Januzzi J. Cardiac markers for myocardial infarction. A brief review. Am J Clin Pathol 2002;118:S93-9. terone and FPSA at the 4 and 8 week intervals post surgically-induced CNVII injury. It is likely that rabbit pathophysiology resembles human pathophysiology in nervous injury, hence these six biomarkers may be of value in managing trauma or idiopathic degeneration of CNVII in humans. The authors hope this study will pave the way for future research in this area.

9. Bandyopadhyay S, Hennes H, Gorelick MH, Wells RG, Walsh-Kelly CM. Serum neuron-specific enolase as a predictor of short-term outcome in children with closed traumatic brain injury. Acad Emerg Med 2005;12:732-8.

10. Vos PE, Lamers KJ, Hendriks JC, et al. Glial and neuronal proteins in serum predict outcome after severe traumatic brain injury. Neurology 2004;62:1303-10.

11. Lima JE, Takayanagui OM, Garcia LV, Leite JP. Use of neuron-specific enolase for assessing the severity and outcome in patients with neurological disorders. Braz J Med Biol Res 2004;37:19-26.

12. Pelinka LE, Kroepfl A, Leixnering M, Buchinger W, Raabe A, Redl H. GFAP versus S100B in serum after traumatic brain injury: relationship to brain damage and outcome. J Neurotrauma. 2004;21:1553-61.

13. Petzold A, Green AJ, Keir G, et al. Role of serum S100B as an early predictor of high intracranial pressure and mortality in brain injury: a pilot study. Crit Care Med 2002;30:2705-10.

14. Thomas DG, Palfreyman JW, Ratcliffe JG. Serum-myelin-basic-protein assay in diagnosis and prognosis of patients with head injury. Lancet. 1978;1:113-5.

15. Shaw GJ, Jauch EC, Zemlan FP. Serum cleaved tau protein levels and clinical outcome in adult patients with closed head injury. Ann Emerg Med 2002;39:254-7.

This is an open access article distributed under the terms of the Creative Commons Attribution-NonCommercial-NoDerivs 3.0 Unported (CC BYNC-ND3.0) Licence (http://creativecommons.org/licenses/by-nc-nd/3.0/) which permits unrestricted noncommercial use, distribution, and reproduction in any medium, provided the original work is properly cited.

Please cite this article as: Kapusuz Z, Özkiriş M, Gencer M, Göçmen A. Y, Dağlioğlu Y. K. Changes in Various Hormone levels in the Rabbit Traumatic Facial Nerve Injury Model. ENT Updates 2018;8(2): 88-92. 